\title{
Treatment of wool fibres with subtilisin and subtilisin-PEG
}

\author{
Carla J.S.M. Silva ${ }^{a}$, M. Prabaharan ${ }^{a}$, Georg Gübitz ${ }^{b}$, Artur Cavaco-Paulo ${ }^{a}$ * \\ ${ }^{a}$ Department of Textile Engineering, Minho University, Campus Azurém, 4800 Guimarães, Portugal \\ ${ }^{\mathrm{b}}$ Department of Environmental Biotechnology, Graz University of Technology, Graz, Austria
}

Received 13 October 2004; received in revised form 6 January 2005; accepted 9 January 2005

\begin{abstract}
In this work the diffusion of serine proteases into wool fabrics and yarns was studied. The proteases used were free subtilisin and subtilisinPEG (the same enzyme that was covalently cross linked to polyethylene glycol). It is shown that the adsorption and diffusion is facilitated by the pre-treatment performed, being the alkaline surfactant washing and bleaching the most effective in what concerns enzyme adsorption. Furthermore, this study suggests that the diffusion of proteases into wool is dependent on the size of the protease. The free enzyme penetrates into wool fibre cortex while the modified bigger enzyme is retained only at the surface, in the cuticle layer. Also, proteins without proteolytic activity do not adsorb considerably on wool due to its hydrophobic nature, therefore the diffusion is facilitated by hydrolytic action.

These results have important practical implications for the establishment of enzymatic wool finishing processes, since they allow for control of the enzyme hydrolysis, which was the major drawback of this environmental friendly option to the conventional chlorine treatments. (C) 2005 Elsevier Inc. All rights reserved.
\end{abstract}

Keywords: Serine proteases; Protein adsorption; Wool fibre; Clean technology; Cross linking

\section{Introduction}

The necessity to use more environmental friendly processes leads to the replacement of conventional chemical textile fibre treatments by enzymatic ones. In the case of wool fibre, there are attempts to substitute the conventional chlorine treatment by an enzymatic process capable of providing the fabric with the same characteristics, like anti-shrinking and anti-pilling behaviour. This could be achieved by using proteases, which would degrade the outermost layer of wool fibre (the cuticle) responsible for wool's undesirable physical properties [1-4].

Wool fibre consists of two major morphological parts: the cuticle and the cortex (see Fig. 1). The cortex comprises spindle-shaped cortex cells that are separated from each other by a cell membrane complex. Wool cuticle cells (overlapping cells that surround the cortex) are subdivided into two main layers, namely the exocuticle and endocuticle [5]. The outer

\footnotetext{
* Corresponding author. Tel.: +351253 510271; fax: +351 253510293.

E-mail address: artur@det.uminho.pt (A. Cavaco-Paulo).
}

surface of the scale of the cuticle is covered by a very thin membrane called the epicuticle. Below this hydrophobic epicuticle is the exocuticle, a cystine-rich component forming about two-thirds of the scale structure. The exocuticle just below the epicuticle is referred to as the 'A' layer, having a distinctly higher cystine component than the rest of the exocuticle (known as the 'B' layer). Below the exocuticle, forming the remainder of the scale structure is the endocuticle and then a thin layer of intercellular cement [6].

The wool cuticle resistance is thought to be due to the naturally occurring covalent isopeptide crosslinks, as well as to covalently attached lipid [7]. Alkali, chlorination and amine treatments are capable of removing some of the bound lipid. These treatments alter the surface properties of the fibre by reducing its hydrophobic nature and enhance textile properties such as dye uptake, polymer adhesion in shrink resist treatments and electrical conductivity [8]. In this study we used pre-treated wool fabrics to improve the diffusion process.

The problem of the enzymatic treatment of wool is that the hydrolytic attack is not limited to the fibre surface and the enzyme diffuses inside it, causing unacceptable strength loss. 


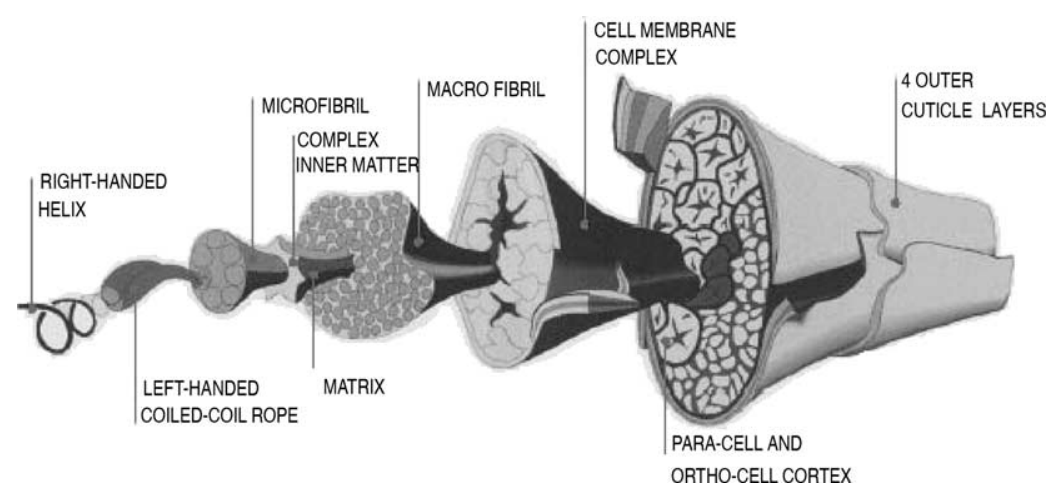

Fig. 1. Cross-section diagram of a merino wool fibre showing the structure at progressive magnifications. Based on [6].

Therefore, reaction control plays a very important role in enzymatic wool finishing. Heine and Höcker [7] have suggested that either the enzyme has to be controlled (for example, diffusion control by enzyme immobilization) or the enzyme has to be specially "designed" (for example, by genetic engineering) in such a way that only a distinct part of the substrate is altered.

The present work analyses and compares the behaviour of two proteases, native subtilisin and polyethylene glycol (PEG)-subtilisin, which differ essentially in their size, in the hydrolytic attack to wool fibres. To contrast with the adsorption and diffusion of the enzymes, two water soluble proteins without catalytic activity, namely bovine serum albumin (BSA) and carbonic anydrase, were used. The major objective of this study was to understand the nature of enzyme-wool interactions which lead to wool degradation, and investigate the possibility of using an enzymatic process for wool finishing, which would be an environmental friendly alternative to the conventional chlorine treatments.

\section{Material and methods}

\subsection{Enzymes, proteins and reagents}

The enzymes used in this study were the proteases Subtilisin Carlsberg (Protease type VIII), (E.C.3.4.21.62) and PEG-subtilisin, a subtilisin that was modified by covalent coupling to polyethylene glycol (6 moles PEG/mol protein), all acquired from Sigma-Aldrich. The proteins bovine serum albumin (BSA), carbonic anydrase and the chemicals fluorescein isothiocyanate (FITC) were from Sigma. All other reagents used were of analytical grade.

\subsection{Enzyme assay and protein concentration}

The activity of proteases was measured, according to Silva et al. [2] using casein as substrate. One unit of activity is defined as the amount of enzyme that hydrolyses casein to produce equivalent colour to $1 \mu \mathrm{mol}$ of Tyrosine, per minute, at $\mathrm{pH} 7.5$ and $37^{\circ} \mathrm{C}$ (colour by the Folin \& Ciocalteu's reagent).
The total protein concentration was determined by a modification of the micro Lowry method [9], using bovine serum albumin as standard and using Sigma test kit no. P 5656. The possible interference of PEG in the estimation of the protein was analysed. For this purpose, standard solutions were prepared (BSA and BSA with 1\% PEG) with concentrations in the range of $0.1-0.5 \mathrm{mg} / \mathrm{ml}$, and the absorbance was determined. No significant changes in the absorbance values occurred when PEG was present (data not shown).

\subsection{FITC linkage to proteins}

Enzymes were linked to FITC (100/1, w/w) in sodium carbonate buffer $\mathrm{pH}$ 8.5. The mixture was dialyzed until no release of FITC was verified by spectroscopy. Wool samples were treated in this solution at $37^{\circ} \mathrm{C}, 100 \mathrm{rpm}$, for $24 \mathrm{~h}$. Wool fibres cross-sections were analyzed by a Transmission optic microscope (Olympus BH2) with magnification of $40 \times$.

\subsection{Tensile strength}

Tensile strength resistance was determined by using a tensile tester machine, accordingly to ASTMD5035-90. The samples were conditioned before testing in a standard atmosphere. The tensile strength resistance values are given as the mean of 10 replicates, together with the standard deviation (the coefficient of variation was bellow $10 \%$ for all cases).

\subsection{Felting and pilling}

Felting and pilling were visually evaluated after repeated washing ( 3 times) at $50^{\circ} \mathrm{C}$, for $60 \mathrm{~min}$ and $20 \mathrm{rpm}$, using a liquor ratio of $1 / 20$.

\subsection{Size-exclusion chromatography (SEC)}

The proteins size was determined by size-exclusion chromatography using a UV-detector at $280 \mathrm{~nm}$ and a Pharmacia Hi-Prep Sephacryl S-300 HR column, under the following conditions: room temperature; eluent: $50 \mathrm{mM}$ 
phosphate, $100 \mathrm{mM} \mathrm{KCl}$, $\mathrm{pH} 6.5$ buffer; flow: $2.5 \mathrm{ml} / \mathrm{min}$ and sample volume of $1 \mathrm{ml}$. Tiroglobulin (669 kDa), Apoferritin $(443 \mathrm{kDa}), \beta$-Amylase $(200 \mathrm{kDa})$, Alcohol dehydrogenase $(150 \mathrm{kDa})$, Bovine albumin $(66 \mathrm{kDa})$ and Carbonic Anydrase $(29 \mathrm{kDa})$ were used for calibration.

\subsection{Adsorption on wool fibres}

The adsorption experiments were performed in flasks each containing equal amounts of the sorbent material: $0.5 \mathrm{~g}$ of $100 \%$ woven merino wool fabric or $23 \mu \mathrm{m}$ (mean diameter) wool yarns, subjected to the different pre-treatments described bellow. Volumes of phosphate buffer solution $(\mathrm{pH}$ 7.6, $0.01 \mathrm{M}$ ) and protein stock solution were added to the sorbent so that every flask contained the same total volume $(50 \mathrm{ml})$ but different protein concentration. Then, the flasks were closed and rotated end-over-end for 7 days for the wool fabrics and for $24 \mathrm{~h}$ for the wool yarns, at $37^{\circ} \mathrm{C}$ and $90 \mathrm{rpm}$, in a shaking water bath. Several controls were run simultaneously: a control test with wool without protein (C1), a control test with the highest concentration of protein without wool (C2) and a control test with the highest concentration of protein and $1 \mathrm{mM}$ of antipain, a serine proteases inhibitor (C3). After incubation, wool fabrics or yarns were removed and washed. The remaining solution was centrifuged and the protein concentration in the supernatant and the amount of aminoacids produced in Tyrosine equivalents were measured. The adsorbed amount of protein was calculated from the difference in protein concentration before and after adsorption. All measurements were performed using at least duplicate samples.

\subsection{Pre-treatments performed on wool fibres}

The pre-treatment washings performed on wool were the following:

- Surfactant washing (S): wool was washed with Lutensol ON 30 (non-ionic surfactant) $1 \mathrm{~g} / \mathrm{l}$, in a bath ratio 1:20, at $\mathrm{pH} 9.0\left(\mathrm{Na}_{2} \mathrm{CO}_{3} 0.1 \mathrm{M}\right.$ and $\mathrm{NaHCO}_{3} 0.1 \mathrm{M}$ buffer), for $30 \mathrm{~min}$, at $40^{\circ} \mathrm{C}$, on Rota-wash machine. After the washing procedure, the surfactant was removed from wool first with tap water, followed by distilled water.

- Bleaching washing $(S+B)$ : After the previous washing, wool was immersed in a bath (same bath ratio) with $1 \%$

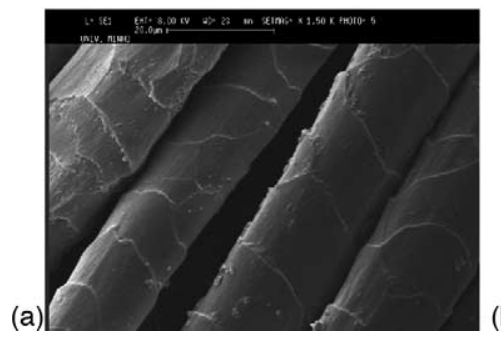

(o.w.f.) $\mathrm{H}_{2} \mathrm{O}_{2}$, at $\mathrm{pH} 9.0\left(\mathrm{Na}_{2} \mathrm{CO}_{3} 0.1 \mathrm{M}\right.$ and $\mathrm{NaHCO}_{3}$ $0.1 \mathrm{M}$ buffer), for $1 \mathrm{~h}$ at $55^{\circ} \mathrm{C}$, on Rota-Wash machine.

\section{Results and discussion}

Proteases can catalyze the degradation of different components of a wool fibre, making reaction control difficult. Fig. 2 shows damaged wool fibres caused by treatment with subtilisin, the protease used in this study. It is also possible to see that the proteolytic attack is not uniform, due to the heterogeneity of the wool itself [10].

\subsection{Effect of pre-treatment}

The wool fibres surface is covered by a covalently bound fatty layer, being responsible for the strong hydrophobicity of wool which can be partially removed by alkaline pre-treatments. To test the effect of the pre-treatment on the adsorption of proteins into wool, merino wool fibres with mean diameter of $23 \mu \mathrm{m}$ were employed. These yarns were subjected to two alkaline pre-treatments in order to enhance the protein penetration inside the fibre. Fig. 3 shows that there are no significant changes on wool surface after the pre-treatments performed (surfactant and bleaching washing).

The protease was added at several concentrations to the pre-treated wool yarns, and the experimental adsorption data

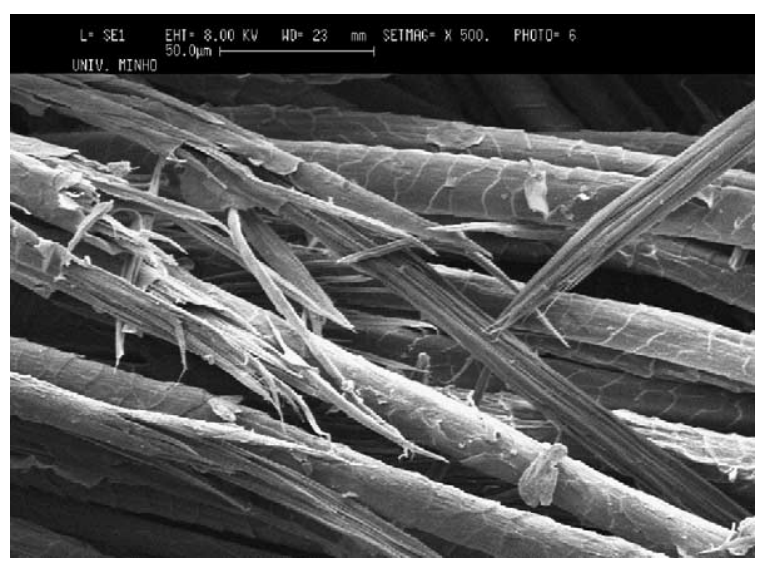

Fig. 2. SEM microphotography showing damaged and undamaged wool fibres after treatment with subtilisin, in $\mathrm{pH} 7.6$ buffer, at $37^{\circ} \mathrm{C}$, for 3 days.

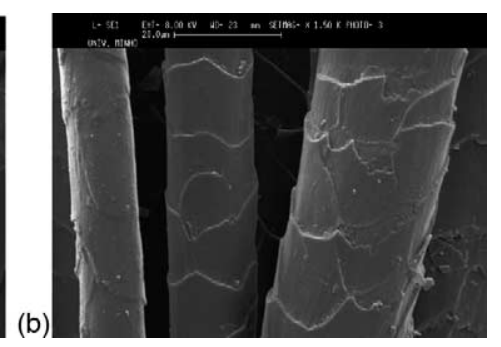

Fig. 3. SEM microphotographs of the wool fibres after the alkaline pre-treatments: (a) surfactant washing, and (b) surfactant and bleaching washing. 


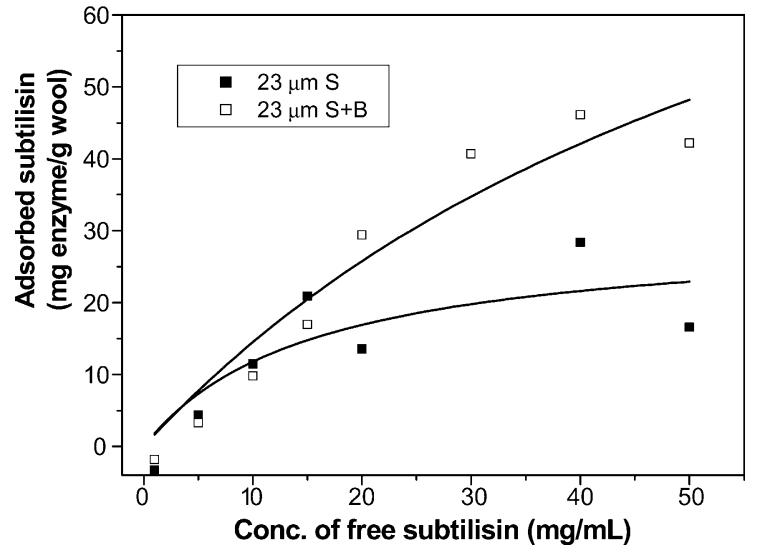

Fig. 4. Langmuir isotherm (-, solid line) and experimental data for the adsorption of free subtilisin on $23 \mu \mathrm{m}$ wool yarns, subjected to a surfactant (S) or a bleaching washing $(\mathrm{S}+\mathrm{B})$.

was fitted by non linear regression analysis to Langmuir model in order to draw the binding curves (Fig. 4).

The Langmuir model did not satisfactorily explain the behaviour of protein adsorption. This was manifested in the poor agreement between the experimental data and simulated curves and also in the low values for the correlation coefficients (data not shown). This was already expected since the wool surface is very heterogeneous, and thus Langmuir model is inadequate to describe adsorption of proteins on this adsorbent.

Observing Fig. 4 it is possible to see that the amount of adsorbed subtilisin was clearly higher for wool that was subjected to a surfactant washing and posterior bleaching. This fact indicates that this pre-treatment enables a higher penetration of proteases into wool and consequently a higher degradation level. The bleaching step with $\mathrm{H}_{2} \mathrm{O}_{2}$ is likely to promote a partial removal of the bounded fatty acid barrier of the epicuticle, probably more efficiently than the alkaline treatment with surfactant only. Schäfer [11], when studying the diffusion of dyestuffs into keratin fibres found that dyestuffs may diffuse quicker into the cortex of bleached wool than into untreated wool because of the cleavage of cystine and the higher fibre swelling. Moreover, Pascual and Julia [12] reported that the sorption of chitosan into wool was facilitated by an alkaline peroxide treatment. Thus one can conclude that a simple alkaline surfactant washing (scouring) is not enough to remove the fatty bounded layer, decreasing considerably the adsorption capacity on wool fibres, when comparing with the other treatment.

\subsection{Effect of enzyme size}

The subsequent studies were performed with $100 \%$ wool fabric subjected to an alkaline surfactant washing followed by bleaching. The enzymes used were the native subtilisin and subtilisin-PEG, a commercial preparation acquired from Sigma. The protein concentrations used were low, so that the surface was never saturated with the enzyme. This study

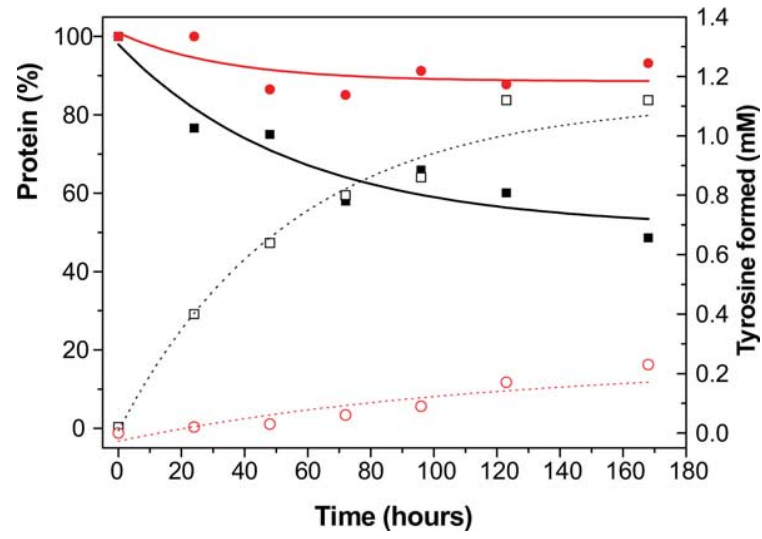

Fig. 5. Formation of Tyrosine (mM) (open symbols) and total protein (\%) (closed symbols) for the enzymes subtilisin $(\boldsymbol{\square}, \square)$ and subtilisin-PEG $(\mathbf{O}, \bigcirc)$.

was performed using an enzyme concentration of $40 \mathrm{mg} / \mathrm{l}$ and for this reason a longer time had to be employed in order to better understand the differences in the behaviour of the two enzymes. Therefore, a study conducted for $168 \mathrm{~h}$ was performed, where protein adsorption and Tyrosine formation were monitored (Fig. 5).

The results (Fig. 5) show that subtilisin-PEG is not being adsorbed (only about $7 \%$ of protein adsorption was attained) while free subtilisin had about $50 \%$ of adsorption into wool fabric. The differences are also noticeable in the formation of Tyrosine equivalents. The subtilisin that was covalently coupled to PEG showed a very low release of aminoacids into media. Comparing to free subtilisin, the amount of aminoacids produced in Tyrosine equivalents was much higher, indicating wool fibre degradation by the enzyme. The control test run simultaneously with free subtilisin and the inhibitor antipain showed no adsorption and no Tyrosine formation, confirming that the adsorption of the protease into wool was assisted by the enzymatic action.

This result was also confirmed by the determination of the fibres strength resistance using a dynamometer. The

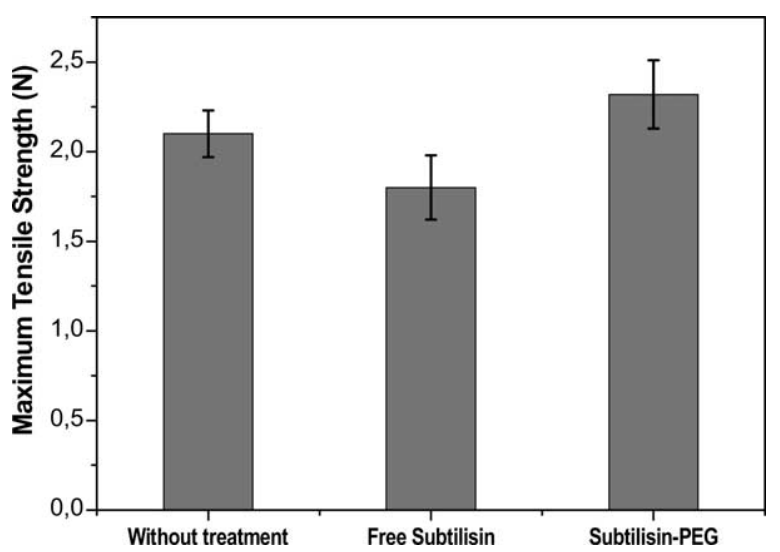

Fig. 6. Maximum tensile strength (N) supported by wool yarns without treatment and yarns treated with the same enzyme units of free and modified subtilisin (CV was less than $10 \%)$. 

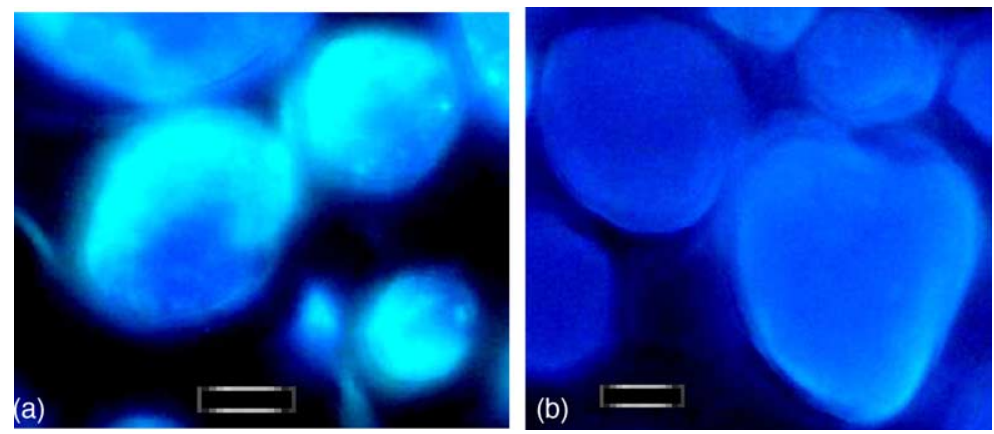

Fig. 7. Fluorescence microphotographs of fibre cross-sections of wool treated with FITC-labelled subtilisin (a) and subtilsin-PEG (b).

maximum tensile strength supported by the yarns was lower for free subtilisin, indicating higher fibre degradation (Fig. 6).

To follow the diffusion of the enzymes into fabrics, they were fluorescently labelled with FITC. After covalently coupling the enzymes to a fluorescent dye (FITC), an extensive dialysis was performed until no release of free dye into solution was verified. Then, after enzymatic treatment, a microtome was used to cut thin layers of the fibre entrapped in a non-fluorescent resin. The figure below shows that free subtilisin penetrates completely inside the fibre cortex while fluorescently labelled subtilisin-PEG only appears at the surface of some fibres (in the cuticle layer). A similar result was found by Nolte et al. [3] when studying the effect of Alcalase, a commercial protease, in wool tops in untreated and Hercosett-treated wool (wool that was treated by the application of a water-soluble resin after chlorination). They found that after a $50 \mathrm{~h}$ treatment, the fluorescently labelled alcalase had fully penetrated the untreated-fibre cortex, while it was retained only at or near the surface of Hercosett-treated fibres after an identical treatment process [3]. They explained this fact by the temporary barrier to the proteolytic attack provided by the polymer treatment (Fig. 7).

To compare with the adsorption of the different size enzymes, the proteins BSA and Carbonic Anydrase, with average molecular weights of 66 and $29 \mathrm{kDa}$, respectively, were also tested for adsorption on wool at several concentrations. These two proteins showed no adsorption on wool, thus the isotherms could not be formulated. The following table (Table 1) presents the Langmuir parameters for all tested proteins. As already mentioned, the Langmuir model does not satisfactorily explain the behaviour of protein adsorption, but its parameters were used on a comparative basis, to check for

Table 1

Values for the relative molecular mass (Mr) and Langmuir parameters $\left(K_{\mathrm{d}}\right.$ and $Q_{\max }$ ), for the several enzymes and proteins tested for adsorption into wool fabrics

\begin{tabular}{lcll}
\hline Samples & $\mathrm{Mr}^{\mathrm{a}}(\mathrm{kDa})$ & $K_{\mathrm{d}}(\mathrm{g} / \mathrm{l})$ & $Q_{\max }(\mathrm{mg} / \mathrm{g})$ \\
\hline Subtilisin & $\sim 20$ & $93 \pm 68$ & $172 \pm 89$ \\
Sub-PEG & $\sim 110$ & - & $<$ Minimum conc. \\
BSA & $\sim 66$ & - & $<$ Minimum conc. \\
Carbonic anydrase & $\sim 29$ & - & $<$ Minimum conc. \\
\hline
\end{tabular}

\footnotetext{
${ }^{\mathrm{a}} \mathrm{Mr}$ are mean values, determined by SEC (Section 2$)$.
}

differences in the adsorption and diffusion behaviour of the two enzymes.

In the above table it is possible to see that the proteins BSA and Carbonic Anydrase were not adsorbed on wool, no matter their size. As for the enzymes, subtilisin-PEG, the large enzyme, was also not adsorbed. Since wool treatments were performed using the same enzyme units in the bath treatment, it seems that the bigger size of subtilisin-PEG is responsible for the limitation verified in the proteolytic attack. This could be explained by the restricted accessibility of this enzyme to wool. The large enzyme molecule is not able to enter in contact with substrate and to form the intermediate enzyme-substrate complex, because of steric constraints. It is known that proteases hydrolyze mainly the inside of the fibre rather than cuticle [13]. This fact is due to the high hydrophobicity of the external surface of wool on one hand, and the fatty layer overlapping the cuticles, on the other. Thus, proteases degrade preferentially the intercellular cement, penetrating under favorable conditions relatively quickly into the fibre cortex [3]. In our study it seems that subtilisin-PEG hydrolyzed just the cuticle layer of wool fibre, explaining the low release of aminoacids and the higher tensile strength resistance of the fibre. To support this idea, wool fibre samples treated with these two enzymes

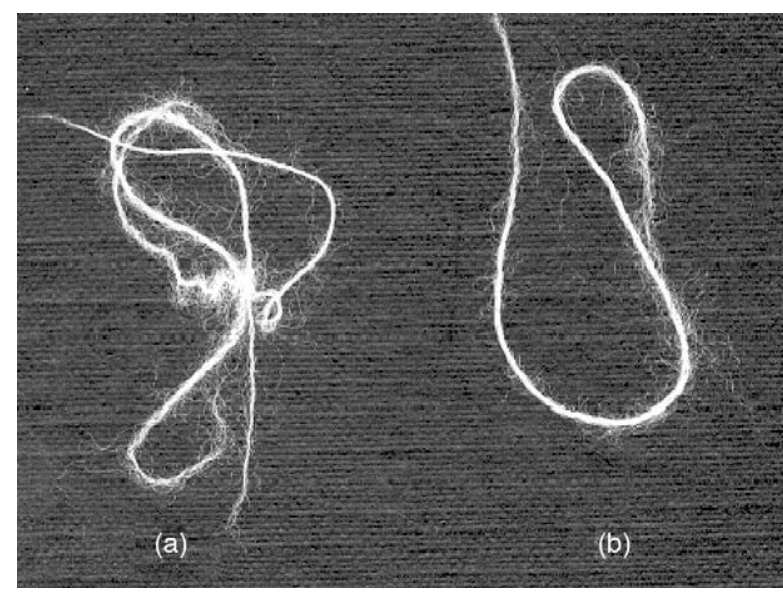

Fig. 8. Visual damages on wool yarns after treatment in a Rota-wash machine. Samples: (a) wool yarn treated with free subtilisin and (b) wool yarn treated with subtilisin-PEG. 
were washed for 3 consecutive cycles in a rota-wash machine and felting was evaluated visually. It seems that wool fibre treated with subtilisin-PEG felted less (Fig. 8), highlighting the idea that it had its cuticle layer partially removed.

This fact could be very useful in wool finishing, where only the cuticle layer is intended to be hydrolyzed. The dimension of the protease is a self-limiting factor for the undesirable hydrolysis of wool fibre cortex, thus overcoming the major drawback of wool enzymatic finishing: the difficulty in controlling enzyme hydrolysis process.

\section{Conclusions}

The adsorption of a native and a modified subtilisin on wool was studied. The alkaline peroxide pre-treatment improves the enzyme diffusion on wool. This diffusion seems to be facilitated by the hydrolytic attack, since proteins without activity could not adsorb considerably on wool.

Subtilisin-PEG, the big protease, hydrolyzed just the cuticle layer of wool, fact that was confirmed by the lower release of aminoacids into media and the higher tensile strength and lower felting of the fibre. Thus, the production of diffusion-controlled enzymes might be a solution for a future enzymatic wool treatment process, which would be an environmental friendly alternative to the conventional chlorine treatments.

\section{Acknowledgements}

The authors acknowledge financial support from FCT (Portugal) via PhD fellowship, ref. PRAXIS XXI, SFRH/ BD/1292/2000 and EU funding for Protex project (G1RD-
CT-2002-00695) and gratefully acknowledge Dr. Jovita Oliveira for performing the fluorescence microscopy analysis.

\section{References}

[1] Silva CJSM, Cavaco-Paulo A. Treatment of animal hair fibers with modified proteases. WO03097927, 2003.

[2] Silva CJSM, Sousa F, Gübitz G, Cavaco-Paulo A. Chemical modifications on proteins using glutaraldehyde. Food Technol Biotechnol 2004;42(1):51-6.

[3] Nolte H, Bishop DP, Höcker H. Effects of proteolytic and lipolytic enzymes on untreated and shrink resist treated. Wool J Text Inst 1996;87(1):212-26.

[4] Cortez J, Bonner PLR, Griffin M. Application of transglutaminases in the modification of wool textiles. Enzyme Microbial Technol 2004;34:64-72.

[5] Plowman JE. Proteomic database of wool components. J Chromatogr B 2003;787:63-76.

[6] Feughelman M. Introduction to the physical properties of wool, hair and other $\alpha$-keratin fibres. In: Mechanical properties and structure of alpha-keratin fibres: wool, human hair and related fibres, UNSW Press:1997;p. 1-14.

[7] Heine E, Höcker H. Enzyme treatments for wool and cotton. Rev Prog Coloration 1995;25:57-63.

[8] Brack N, Lamb R, Pham D, Turner P. Nonionic surfactants and the wool fibre surface. Colloids Surf Physicochem Eng Aspects 1999;146:405-15.

[9] Lowry OH, Rosenberg WJ, Farr AL, Randell RJ. Quantitation of protein using Folin Ciocalteau reagent. J Biol Chem 1951;193:265-75.

[10] Rippon JA. The structure of wool. In: Wool dyeing, Lewis, DM (Ed.). Bradford: Society of Dyers and Colourists, 1992:p. 1-51.

[11] Schäfer K. Microscopical investigation of the diffusion of dyestuffs into keratin fibres. Wool Tech Sheep Breed 1994;42(1):59-82.

[12] Pascual E, Julia MR. The role of chitosan in wool finishing. J Biotechnol 2001;89:289-96.

[13] Sawada K, Ueda M. Enzyme processing of textiles in reverse micellar solution. J Biotechnol 2001;89:263-9. 